\title{
The second edition of the EPAC expert survey on ethnonationalism in party competition - testing for validity and reliability
}

\author{
Christina Isabel Zuber ${ }^{a}$ and Edina Szöcsik ${ }^{b}$ \\ aPolitics and Public Administration, University of Konstanz, Konstanz, Germany; ${ }^{\text {bPolitical }}$ \\ Science, University of Basel, Basel, Switzerland
}

\begin{abstract}
This research note presents EPAC 2017, a dataset resulting from the second round of an expert survey on ethnonationalism in party competition. EPAC provides cross-sectional data on the positions of (ethno-) national and mainstream parties on an ethnonational (also often referred to as 'territorial' or 'centre-periphery') dimension, as well as other important dimensions of political competition. The 2017 edition covers 222 political parties in 22 multinational European countries. The research note presents the main survey items and performs a series of validity and reliability tests on the data. Results show that EPAC 2017 provides valid and reliable measures of party positions on an ethnonational dimension. A short analysis of party system changes in Spain and Bosnia and Herzegovina illustrates the opportunities of combining the 2011 and 2017 editions. The combined dataset allows studying the mobilization of the centre-periphery cleavage in party competition across Eastern and Western Europe and over time.
\end{abstract}

KEYWORDS Expert survey; territorial politics; centre-periphery; nationalism; party competition

\section{Introduction}

This research note evaluates the reliability and validity of the EPAC 2017 dataset, the second round of an expert survey on ethnonationalism in party competition. The first round was originally conducted in 2011 to provide so far missing, European-wide data on the positions that ethno-nationalist parties (often also referred to as 'ethno-regionalist' or 'minority nationalist' parties) and mainstream parties ${ }^{1}$ adopt on an ethnonational dimension (often also referred to as 'territorial' - e.g. Basile 2015 - or 'centre-periphery dimension' - e.g. Alonso 2012; Massetti 2009), as well as other important dimensions of political competition. EPAC 2017 now adds a second time point as well as new questions on European integration and immigration to

CONTACT Christina Isabel Zuber mail@christinazuber.com Fachbereich fur Politik- und Verwaltungswissenschaft, Universitat Konstanz, Konstanz 78457, Germany 
the original dataset. Between September 2016 and January 2017, a total of 210 country experts evaluated the policy positions of 222 political parties in 20 multinational European democracies, as well as in the Ukraine and Turkey. ${ }^{2}$

We hope to encourage researchers to continue bridging the divide between the fields of ethnic and territorial politics and the divide between scholars studying territorial party politics in Eastern and Western Europe. Scholars study centre-periphery competition in post-communist, Eastern European democracies in terms of 'ethnic politics', whereas they tend to use the label of 'territorial politics' for Western European democracies. Our goal is to cover political parties that are similar in type and constitute a party family, even though researchers use a broad array of different labels to refer to them (see Hepburn 2009a, 480-485 for an overview). We select all parties that aim to represent territorially concentrated (ethno-) national majority and minority groups in politics, no matter whether these parties are referred to as ethnic, ethno-national, ethno-regionalist, nationalist, rightwing populist, minority nationalist, or stateless nationalist and regionalist parties in the literature.

Reference to a homeland territory of a cultural group is the essential attribute characterizing parties that mobilize the centre-periphery cleavage:

Today the term 'periphery' is used to designate 'territorial units with a differentiated history within the state, territories that are home to cultural minorities and that at the time of the state- and nation-building processes were subject to the homogenization policies of the state's central elites'. (Alonso, Gómez, and Cabeza 2013, 190; citing Alonso 2012, 24)

However, we acknowledge that in addition to a shared homeland territory, both majority and minority nationalism can be constructed in very different ways. It can be tied to the idea of shared ethnicity in the narrow sense, that is, the belief in a community's common descent from shared ancestors (Chandra 2006), as in the case of German-speakers in South Tyrol or Hungarians in Transylvania. But it can also be constructed on the basis of a common language, culture, and history, as in the case of Catalonia (Guibernau 1997), or a social-democratic vision of a just society, like in Scotland (Hepburn 2009b).

In line with this reasoning, we select all European countries where the centre-periphery cleavage is politically mobilized, independent of whether they are located in the Western, or the post-communist, Eastern part of the continent. As a criterion for the existence of mobilized peripheral groups, we draw on the EPR-ETH data on ethnic power relations (Cederman, Wimmer, and Min 2010). Even though the EPR-ETH project focuses on politically relevant ethnic groups in its title, its definition of an ethnic group is wide enough to cover groups in Europe that are generally not labelled as ethnic by country experts, such as Catalans or Scots: 
We define ethnicity as any subjectively experienced sense of commonality based on the belief in common ancestry and shared culture. Different markers may be used to indicate such shared ancestry and culture: common language, similar phenotypical features, adherence to the same faith, and so on. (Cederman, Wimmer, and Min 2010, 98-99)

Since many researchers working on Western European cases do not understand ethnicity in this wider sense (e.g. covering also groups based on a shared language and culture), we bracket the term ethno- in referring to (ethno)- national groups both in the survey as well as in this article.

We hope that the availability of comparative, standardized and systematic data will inspire scholars traditionally studying parties in contexts like Catalonia or Scotland to embark on searching for differences and commonalities in the behaviour of parties in contexts like Transylvania (Romania) or Vojvodina (Serbia), thereby allowing for a truly comparative European approach to centre-periphery competition.

Last but not least, like its predecessor back in 2011, the 2017 version does not only map the positions of parties appealing to identity groups with a territorial basis. Our dataset additionally includes the positions that mainstream parties adopt towards territorial issues, enabling researchers to study the complete pattern of centre-periphery competition in a given party system.

The research note is structured as follows. Section two introduces the survey items. The third section outlines the criteria for selecting countries, parties and experts. Section four presents a series of state of the art tests to examine the validity and reliability of the new data in light of the methodological challenges of measuring party positions through an expert survey. ${ }^{3}$ The results show that EPAC 2017 provides valid and reliable measures of party positions on an ethnonational dimension. We then provide a short analysis of party system change in Spain and Bosnia and Herzegovina in section five to illustrate the opportunities of combining the 2011 and 2017 editions and conclude the research note in section six.

\section{Survey items}

The survey consists of three types of questions: (1) questions related to the mobilization of the centre-periphery cleavage in party competition, (2) questions related to parties' positions on other important dimensions of party competition, and (3) questions asking experts about their own position and distance to the political parties. The latter information can be used to test for expert bias. For each dimension, the survey uses eleven-point scales with positions ranging from zero to ten and a centre position at five. Experts can also state that a party has no position on a given issue or that they do not know the position of a party on a given issue. Further, we asked experts how important every issue is for each party, again using 
eleven-point scales that range from 'not important at all' (0) to 'extremely important' (10).

The first three survey items are related to what we refer to as the ethnonational dimension of party competition (and what others have referred to as the territorial or centre-periphery dimension of party competition, e.g. Alonso 2012; Basile 2015; Massetti 2009). The first item asks experts for the general ethnonational positions taken by parties, with assimilationist majority nationalism demarking one extreme pole, and secessionist minority nationalism the other (for the exact wording of all survey items, see appendix E). The next two items ask experts to identify parties' stances on the principles of cultural and territorial autonomy for national minority groups. ${ }^{4}$ On all three scales, position zero $(0)$ refers to the situation where a party opposes granting any special rights to a minority group on the basis of its distinctive (ethno-) national identity. Position ten (10) corresponds to a maximalist minority nationalist position. To these three scales, we add a question about the territorial model of state organization preferred by each party, allowing for a choice between the following answer categories: (a) unitary state, (b) decentralization, (c) decentralization on ethnic base, (d) symmetrical federalism, (e) asymmetrical federalism, $(f)$ independence for a national minority region and (e) annexation of the minority region by another state. It was not possible to tick multiple answers. Closing this section of the survey, we asked experts whether the party seeks to represent (ethno-) national groups and regions in politics. Unlike in 2011, we now bracketed the word 'ethno' in this question to indicate that the national groups a party seeks to represent need not be socially constructed on the basis of ethnicity. This information can be used to classify parties into majority and minority nationalist and/or regionalist parties.

In the second part of the survey, we proceeded to ask experts about parties' stances on other important dimensions of political competition. We first asked for parties' stances on the economic and the cultural dimension of party competition, adopting two questions from the Chapel Hill Expert Survey (Bakker et al. 2015; Hooghe et al. 2010). The next two items asked for parties' stances on European integration and immigration, a new addition in this round of the survey.

In addition, we asked experts for their own position on the general ethnonational dimension, as well as the economic and cultural dimensions, and how close they feel to each of the parties listed in the survey. These items are used in the analysis probing for expert bias in section three.

\section{Selection criteria}

For EPAC 2011, we had originally selected all European democracies where ethnonational identity categories are considered to be politically mobilized 
drawing on country assessments provided by the EPR-ETH dataset (Cederman, Wimmer, and Min 2010). EPAC 2017 sticks to this original selection of countries. This implies that although according to the Polity IV project, democracy has eroded in Turkey and the Ukraine since 2011 when we first administered the survey, we kept Turkey and the Ukraine in our country selection to be able to track the development of parties' positions over time. ${ }^{5}$ For the resulting sample of 22 European multinational countries, 222 political parties were selected according to the criteria applied in Szöcsik and Zuber (2015). We selected all (ethno-) national parties, defined as parties that appeal centrally to a territorially based ethnic or national identity category to the exclusion of others where the group had to be listed in the EPR-ETH project as a politically relevant ethnic group. ${ }^{6}$ Note that this definition covers also parties appealing exclusively to the majority group, i.e. majority nationalists. The classification of parties was based on secondary sources and party websites. (Ethno-) national parties were listed in the survey if they managed to gain at least one seat in the national parliament in the most recent parliamentary elections as of September 2016, or at least one seat and at least $3 \%$ of the subnational votes in at least one region in the last regional elections as of September 2016. ${ }^{7}$ Second, we selected nonethnic parties if they had gained at least $5 \%$ of the national vote share in the most recent elections as of September 2016. In order to enable timeseries analysis wherever possible, we additionally included parties formerly included in the 2011 edition even if they no longer passed the criteria for inclusion in 2016, if we found evidence that the party was still actively competing in at least regional elections within the minority region.

In Eastern Europe, minority nationalist parties often contest elections as members of a pre-electoral alliance. If parties ran as part of an electoral alliance, we tried to get information about the seats awarded to each individual party that formed part of the alliance based on the parliament's website. We included (ethno-) national parties that ran as part of an alliance if they gained at least one seat in the national parliament or if they gained at least 3\% of seats in the regional parliament. This means that we applied our regional vote criterion to the seat shares instead of the vote shares, since for parties that ran as part of an electoral alliance, no information on individual vote shares is available. In cases where we could not find detailed information allowing us to break the seats allocated to the alliance down to individual parties, we included the first listed party (most often the leader of the alliance) or the name of the alliance into the survey, if the alliance as a whole passed our criterion of relevance.

For our pool of experts we again chose only social scientists with at least an M.A. degree and published research on party competition and/or on ethnonationalism/majority-minority relations in the respective country. We included only academics that were either employed at a higher academic institution 
or an independent research institution/think tank. Like last time, we aimed to include experts with a majority and a minority background into our database in the hope that potential biases when rating the same parties would cancel each other out (Szöcsik and Zuber 2015, 155). Our goal was again to collect at least four surveys per country, a benchmark applied by the Chapel Hill Expert Survey in the past (Hooghe et al. 2010, 692). This goal was surpassed in all countries except for Latvia (four surveys). The highest number of surveys was returned in Spain (19) and Macedonia (17). Overall, 566 surveys were sent out and 201 completed surveys were returned, yielding a response rate of 35.51\%, a slight improvement over 2011 (cf. Appendix A). ${ }^{8}$

\section{Evaluating the validity and reliability of EPAC 2017}

In the following, we examine whether the new data provide valid and reliable measures of an ethnonational dimension of party competition, addressing potential problems of validity and reliability associated with expert surveys in the literature (see Table 1, adapted from Szöcsik and Zuber (2015). The analyses draw on two types of data, the summary data with mean expert ratings and the raw data with individual expert ratings.

\section{Construct validity}

Table 2 presents the results of confirmatory factor analysis (Brown 2006) to evaluate whether parties' stances on the three scales of ethnonationalism, cultural autonomy, and territorial autonomy correlate enough to warrant the assumption that they reflect a single, underlying dimension of party

Table 1. Validity and reliability problems of expert surveys.

\begin{tabular}{|c|c|c|}
\hline Level & Problem & Method for Diagnosis \\
\hline Measurement & $\begin{array}{l}\text { Survey items do not measure the } \\
\text { ethnonational dimension of party } \\
\text { competition } \\
\rightarrow \text { No construct validity }\end{array}$ & $\begin{array}{l}\text { Confirmatory factor analysis shows that the } \\
\text { three survey items are not associated with } \\
\text { the same underlying construct }\end{array}$ \\
\hline Intra-expert & $\begin{array}{l}\text { Biased expert judgments } \\
\rightarrow \text { Low internal validity }\end{array}$ & $\begin{array}{l}\text { 1) Experts have non-centrist positions on the } \\
\text { ethnonational dimension } \\
\text { 2) OLS regressions show that party placements } \\
\text { are systematically associated with experts' } \\
\text { own policy preferences (only possible for } \\
\text { Spain) }\end{array}$ \\
\hline Inter-expert & $\begin{array}{l}\text { Variance of expert judgments } \\
\rightarrow \text { Low reliability }\end{array}$ & $\begin{array}{l}\text { 1) High standard errors of mean party positions } \\
\text { 2) Variance components analysis shows high } \\
\text { variance of experts' judgments when placing } \\
\text { the same party on the same scale }\end{array}$ \\
\hline Dataset & $\begin{array}{l}\text { EPAC biased } \\
\rightarrow \text { Low external validity }\end{array}$ & $\begin{array}{l}\text { Placement of parties diverges from party } \\
\text { placements in other datasets, notably the } \\
\text { Regional Manifestos Project (Gómez, Alonso, } \\
\text { and Cabeza 2009). }\end{array}$ \\
\hline
\end{tabular}

Note: Table adapted and up-dated from Szöcsik and Zuber $(2015,155)$. 
Table 2. Measurement model for the ethnonational dimension of party competition.

\begin{tabular}{lcc}
\hline Construct: Ethnonational dimension of party competition & \\
\hline Items (measured on 11-point-scales ranged 0-10) & Non-standardised loading & Standardised loading \\
Position on ethnonationalism (ethno_m) & 1 & 0.954 \\
Position on cultural autonomy $($ cul_m) & $1.047^{* * *}(0.035)$ & 0.952 \\
Position on territorial autonomy (ter_m) & $1.247^{* * *}(0.047)$ & 0.918 \\
$N=222$ & &
\end{tabular}

Notes: Standard errors are given in parentheses; ${ }^{* * *} p<0.001$.

With three indicators for the latent construct the model is just identified, with zero degrees of freedom. Common fit indices can therefore not be computed.

competition. The model was tested through maximum likelihood estimation using STATA 14.

The two freely estimated factor loadings are significant at the 0.001 level. Standardized loadings range from 0.92 to 0.95 , which indicates that all items are salient. This demonstrates high construct validity. Additionally, since the scales of all indicator variables are identical, the similar values of the unstandardized loadings further corroborate the conclusion that the three indicators validly measure the same underlying construct.

\section{Expert bias}

The insight that experts' own political preferences may influence their placement of political parties originates from social judgment theory. On the one hand, moderate experts are expected to evaluate parties more correctly than experts with extreme positions who are expected to pull preferred parties towards their own position and push parties they dislike away from their positions (Curini 2010; Granberg and Brown 1992, 728). On the other hand, experts might generally dislike extreme parties and distort their placement, independent of whether they are themselves moderates or not (see Curini (2010) for extreme right parties). ${ }^{9}$

To assess to what extent we are dealing with moderate experts, we asked experts to state their own policy positions on ethnonationalism, as well as on the economic and the cultural dimensions of party competition. A majority of $66.29 \%$ of all experts located themselves at the moderate middle point (5) of the ethnonationalism scale and with two exceptions, (5) was also the dominant answer category within each individual country. In Romania and the UK we find equal numbers of experts locating themselves on the middle point and on a position towards the minority nationalist end of the scale. In general, however, even if they did not tick the centrist position (5) on the ethnonational dimension, experts tended to tick positions within the moderate middle range (4-6). An exception is Spain where we find the full spectrum ranging from extreme majority (1) to extreme minority nationalist positions (10), as shown in Figure 1. Luckily, we can subject the Spanish data to more 
detailed tests for expert bias, since the number of responses is large enough to estimate the effect of expert bias through regression analysis as suggested by Curini (2010, see analysis below).

Experts are also moderate centrists on economic issues (mean of 4.8 across all countries, (5) being the most frequently ticked answer category), but are clearly leaning towards the libertarian end of the cultural dimension (mean of 2, and an extremely libertarian position (1) as the most frequently ticked answer category). This implies that our data could potentially suffer from expert bias in case of the cultural dimension, where experts might have tended to push parties with traditional and authoritarian positions away from their own, libertarian position and pull parties with libertarian positions further towards the libertarian end of the spectrum than they would actually deserve.

Regression analysis can be employed to estimate whether there is a significant effect of experts' own policy preferences on their placements of political parties, independent of whether the experts in question are themselves moderate or not (Curini 2010). For the original analysis, Curini (2010) drew on Benoit and Laver's expert survey (2006). In our case, the number of expert answers per party is much lower but we can test for expert bias for parties in Spain, the case where we received the highest number of completed surveys. At the same time, Spain is a hard test case for our data, since as shown above, among Spanish experts we find moderate ones, but also those that take a more extreme stance in the centre-periphery conflict. This

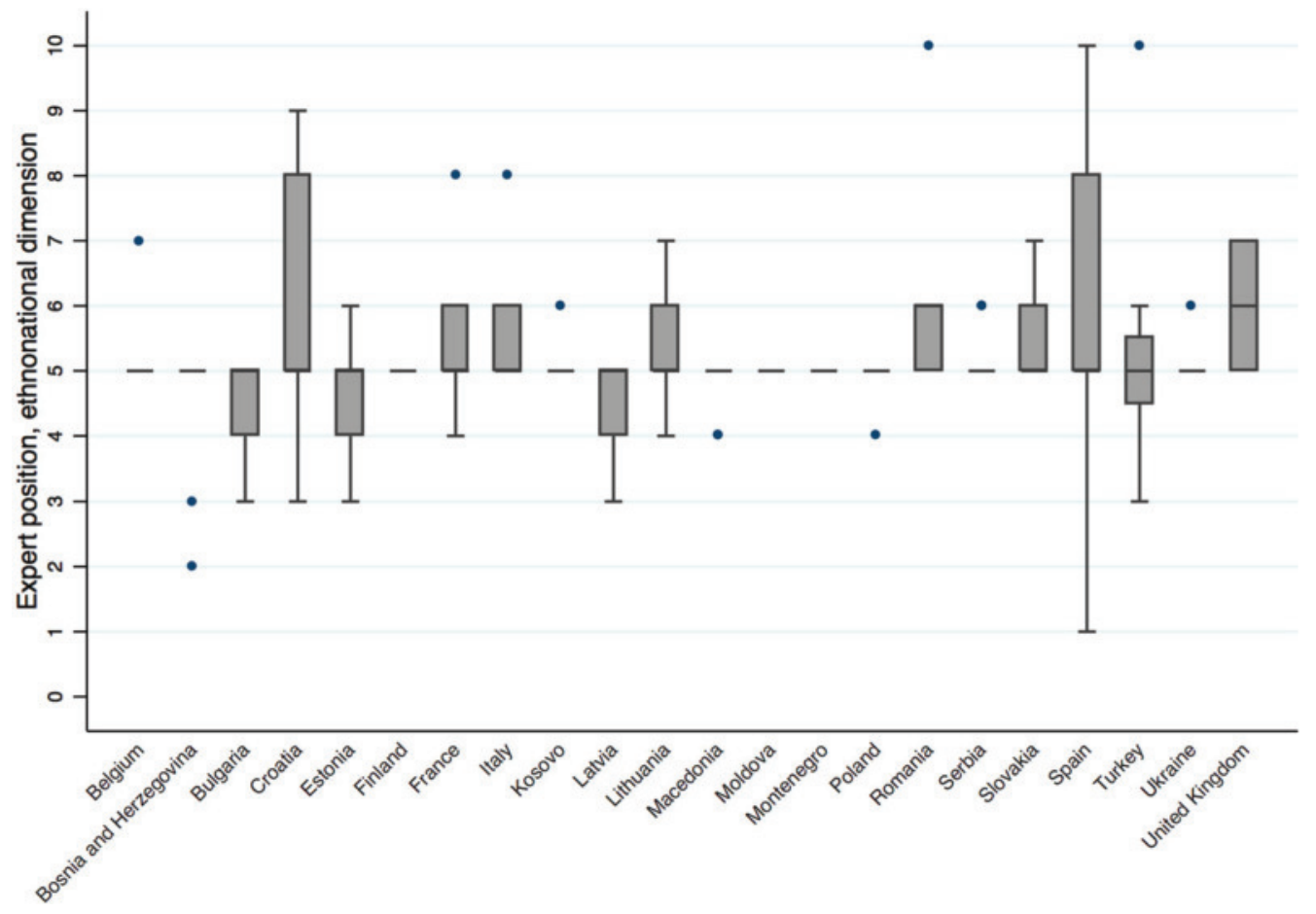

Figure 1. Experts' own position on the ethnonational dimension by country. 
conflict was highly salient due to Catalan separatist mobilization at the time of conducting the survey. At the conventional 0.05 level, we found evidence of expert bias for two out of twelve Spanish parties for the ethnonational dimension. ${ }^{10}$ Given that Spain is a most likely case for bias on the ethnonational dimension, we have reason to expect equal or less, but not more, instances of biased ethnonational placement of parties in our other cases (for detailed regression results, see Appendix B).

\section{Reliability}

Low variance in the ratings of several experts of one party on a given scale indicates that the party's position is measured reliably. We therefore assessed the variance of expert judgments in two ways. First, following Benoit and Laver $(2006,176)$, standard errors were computed as the standard deviation of the expert placements divided by the square root of the number of placements minus one. Mean standard errors of party ratings across the entire data set are smaller than one point on the measurement scale, ranging from 0.58 for ethnonationalism and territorial autonomy to 0.98 for the salience of immigration. However, there are significant outliers (see appendix $C$ where we plotted standard errors on different issue dimensions).

Second, we analysed why experts diverge when placing the same party on the same scale and estimated a multilevel regression model with the standard deviation of parties' positions as the dependent variable. Similarly to Steenbergen and Marks' analysis $(2007,353)$, we include parties' electoral strength and the salience of a given issue for the party into our analysis, assuming that these variables reduce uncertainty of experts' judgments. It might be easier to assess the positions of (ethno-) national than those of mainstream parties on ethnonationalism, cultural and territorial autonomy, whereas the reverse might be the case for the economic dimension, as well as immigration and European integration. We therefore include a dummy variable for whether the party belongs to the family of (ethno-) national parties. We further expect that it is easier to place parties that compete in elections at all levels than those that only compete in one region and include a dummy for whether the party only competes at the regional level (regional party), or also at the national level. We also include two country-level variables into our analysis: First, the variable party differentiation within a party system is measured as the standard deviation of party positions in that country (Steenbergen and Marks 2007) and we assume that if parties have more diverse positions on an issue, experts can more reliably judge their positions. Second, we include a dummy variable for Eastern European countries or Turkey (Eastern Europe). We assume that experts can more easily identify parties' positions in Western Europe where party systems are more stable and more institutionalized. Finally, we include the effective number of experts that provided a 
rating for a given party into our analysis as a control variable, again following Steenbergen and Marks (2007).

The results in Table 3 show little systematic influence of these independent variables on the standard deviation of party positions. For two out of seven issues and dimensions, party differentiation leads to smaller standard deviations. If parties differ more strongly in their positions on cultural autonomy and on the cultural dimension, standard deviations are significantly smaller. In one case, the variable ethnonational party has a significant negative impact. In the case of the cultural dimension, standard deviations in expert judgements are significantly smaller for ethnonational parties than for nonethnonational parties. The variables salience, regional party and number of experts sometimes have a significant positive, other times a significant negative or no significant coefficient. Finally, the variable Eastern Europe does not have a significant influence on the standard deviation in expert judgements in any case. All in all, the uncertainty of experts across issues and dimensions does not seem to be robustly associated with any of the causes identified in the literature and, as a consequence, standard errors appear to reflect random, rather than systematic measurement error.

Finally, we evaluate the variance across experts by calculating a variance components analysis following Steenbergen and Marks (2007). Table 4 presents the results of variance components analysis of the variables ethnonationalism, cultural autonomy and territorial autonomy, and for the variables that measure the salience of the positions on these issues. Additionally, we calculated the inter-expert correlation ${ }^{11}$ and the reliability via the Spearman-Brown formula (Steenbergen and Marks 2007, 363). ${ }^{12}$ The inter-expert correlation for the variables ranges from 0.637 (salience of territorial autonomy) to 0.943 (territorial autonomy). Reliability ranges from 0.933 (salience of territorial autonomy) to 0.993 (territorial autonomy). These results indicate high expert convergence and provide evidence of a very high reliability of the 2017 data on party positions on the ethnonational dimension of competition. ${ }^{13}$

\section{Convergent validity}

Opportunities for assessing whether our indicators for parties' stances on an ethnonational dimension are empirically associated with alternative indicators of the same concept (Adcock and Collier 2001,54) are limited. Large comparative projects collecting data on party positions such as the Chapel Hill Expert Survey series (Bakker et al. 2015; Hooghe et al. 2010) and the Manifesto Project Database (Lehmann et al. 2017) do not include valid measures of an ethnonational (or territorial) dimension of competition. An exception is the Regional Manifestos Project (Gómez, Alonso, and Cabeza 2009, hereafter RMP). The project is interested in party positions on the centre-periphery dimension and in competition at the regional level. It has been previously validated 


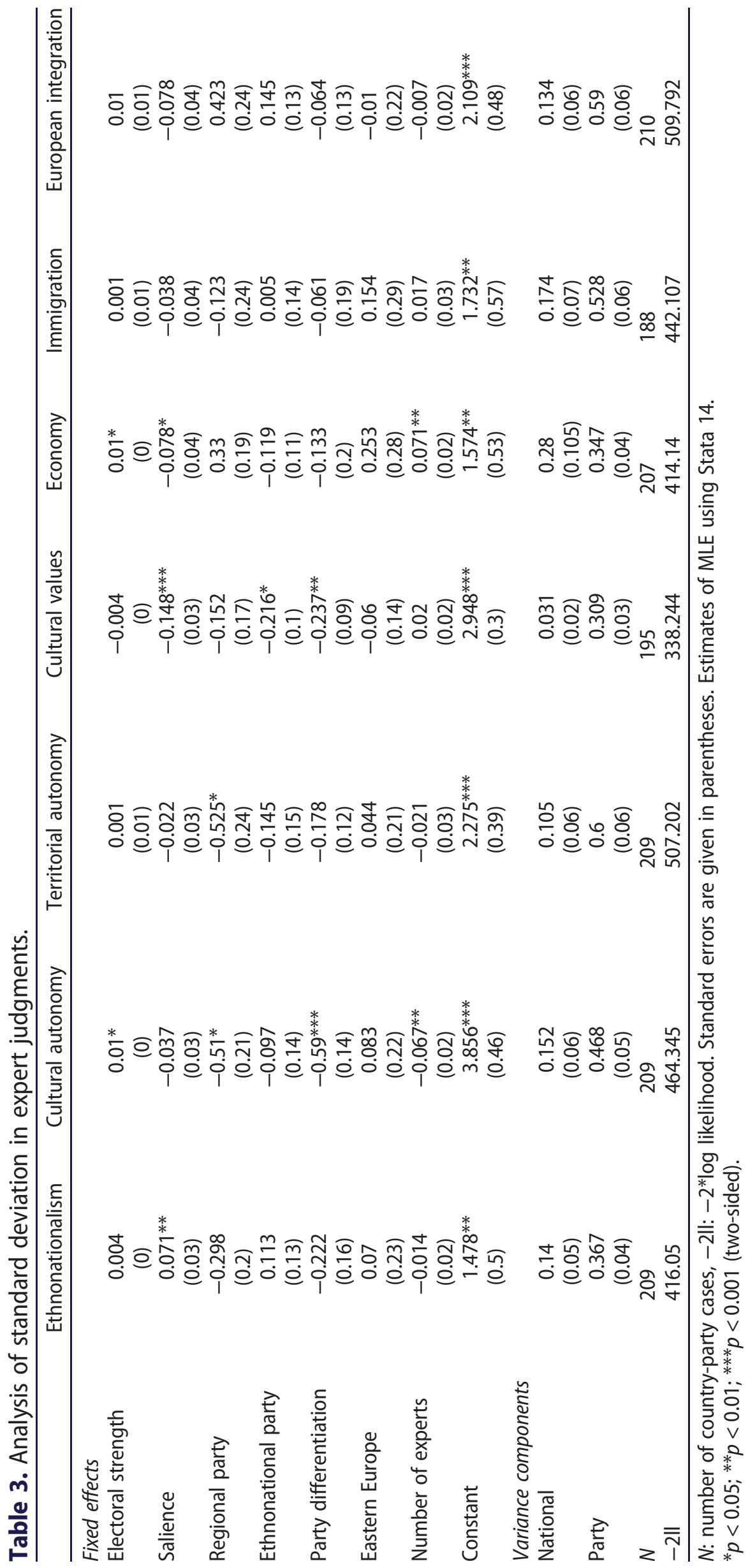




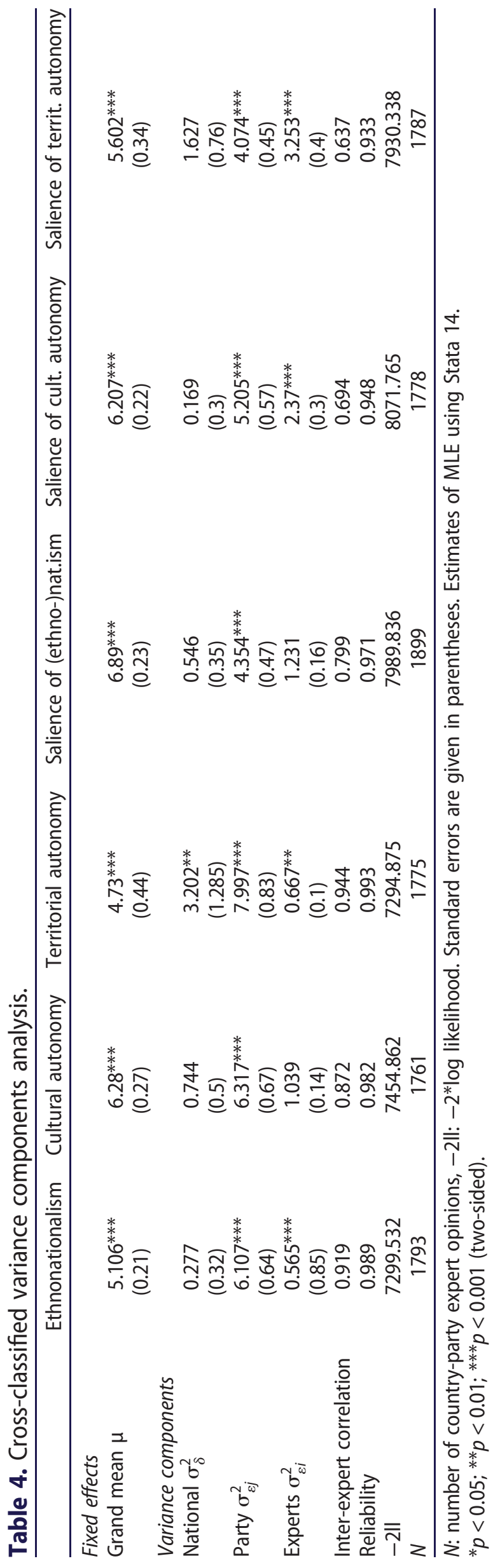


against our data collected in 2011 (Alonso, Gómez, and Cabeza 2013, 206207). The current release of the Regional Manifestos Project covers parties' positions in regional elections in Spain and the UK until 2015. In addition, we obtained early access to RMP data for parties in the Italian province of South Tyrol and for more recent elections in Spain and the UK (Scantamburlo, Alonso, and Gómez 2018). It has to be noted that state-wide, mainstream parties are only included into RMP for the case of Spain.

To test for convergent validity, we combined the 2011 and 2017 measures and estimated the correlation between parties' position on the ethnonational dimension (EPAC) and their centre-periphery position in regional politics (RMP). RMP measures the centre-periphery position of parties by calculating the difference between the share of pro-periphery and the share of pro-centre quasi sentences for each manifesto (see Alonso, Gómez, and Cabeza 2013, 202-3). Theoretically, parties' centre-periphery positions can therefore vary from -100 (fully pro-centre) to 100 (fully pro-periphery). The assumption is that position 0 denotes a neutral position. It can come about either through the absence of any pro-centre or pro-periphery statements or through an equal share of pro-centre and pro-periphery quasi-sentences. In order to compare parties' positions on the centre-periphery dimension as measured by RMP to their positions on the ethnonational dimension as measured by our project, we rescaled the RMP data so that -100 on the RMP scale corresponds to 0 on the ethnonational scale, 0 on the RMP scale to 5 on the ethnonational scale, and 100 on the RMP scale to 10 on the ethnonational scale. The correlation between the positions of the 20 parties included in both EPAC and RMP is 0.57 (significant at the 0.01 level). ${ }^{14}$ This correlation is very satisfying, given that the two datasets rely on different methods of data collection, partly measure parties' positions in different years and at different levels of party competition: the regional manifestos project analyses electoral manifestos prepared for regional elections. By contrast, experts who participated in our survey were asked to evaluate the stance of the party leadership, without specifying the level of competition. ${ }^{15}$

Comparing parties' positions in the two datasets as displayed in Figure 2, we can see that in the case of Spain (where RMP also covers the mainstream People's Party (PP) and the Social Democrats (PSOE)), state-wide parties have a less minority friendly position than minority nationalist parties following both datasets. However, the positions of state-wide and minority nationalist parties are more polarized in our dataset than in the RMP. This could be because parties face strategic incentives to present more moderate positions with regard to the centre-periphery conflict in their official documents than in their public discourse. Unlike the RMP that is exclusively based on parties' explicit statements in their electoral manifestos, experts' assessment of a party's position is based on a variety of different types of evidence (e.g. speeches of party leaders, media reports, commentaries, questions raised in 


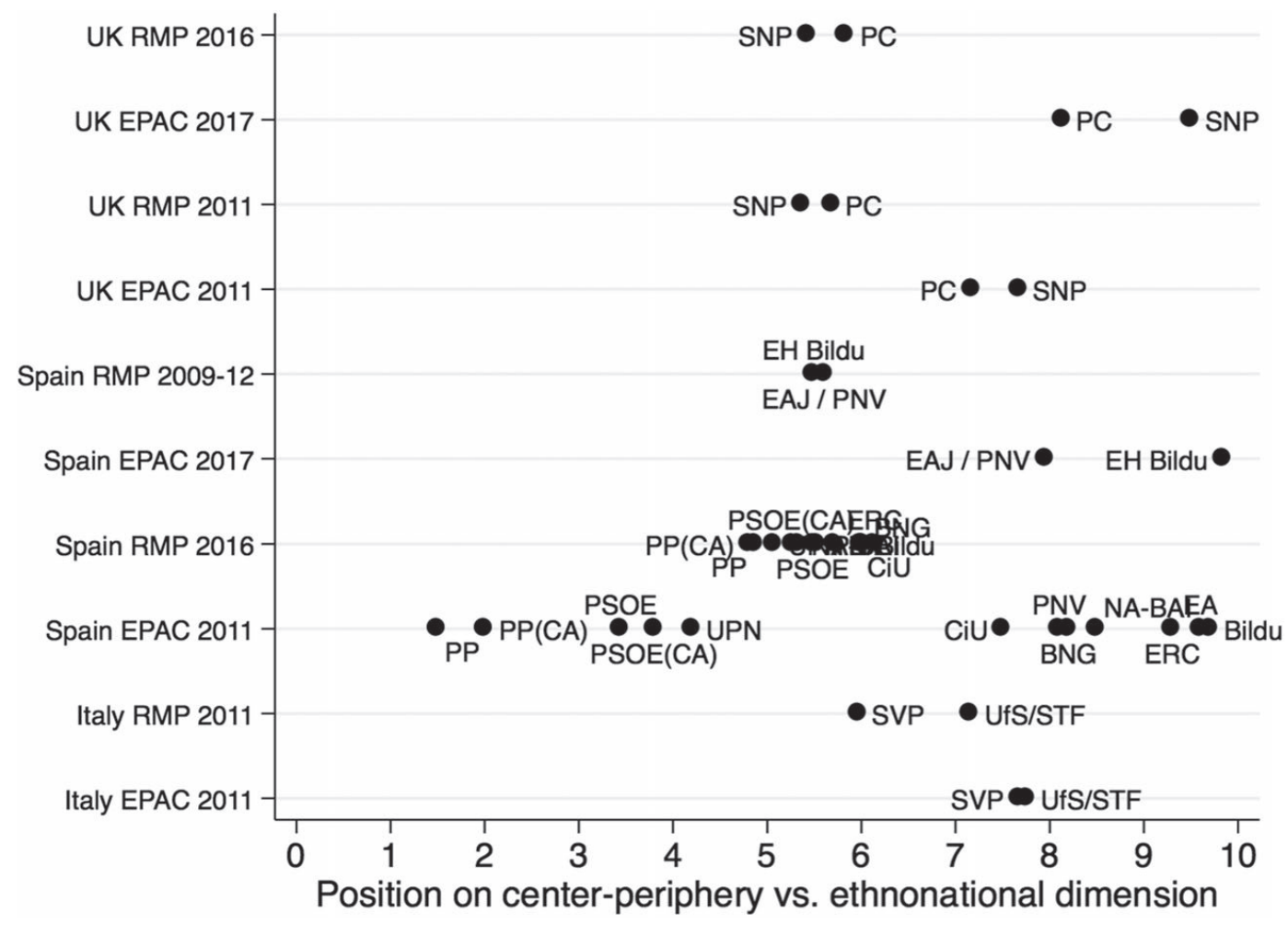

Figure 2. Comparing parties' positions according to RMP and EPAC.

parliament, or their policies). In addition, party positions of the RMP are calculated on the basis of saliency scores, that is, they are based on the relative emphasis parties place on topics, and where more emphasis on topic $A$ means less emphasis on topic $B$ in a given party manifesto. In contrast, our data does not infer party positions on the basis of relative emphasis but asks experts directly for positional information.

\section{Party competition in Spain and Bosnia and Herzegovina - face validity and opportunities of the combined dataset}

In the following, we analyse the development of centre-periphery competition over time in an Eastern and a Western European context to show the potential of combining the 2011 and 2017 data and assess whether casebased evidence corresponds to insights drawn from our larger, cross-nationally comparative data collection. Spain and Bosnia and Herzegovina both have a mobilized and highly salient centre-periphery conflict. In Spain, EPAC covers the positions of Spanish state-wide, Basque, Galician and Catalan parties and during our period of observation, in particular the conflict between Catalonia and the central state had been gaining momentum since the Constitutional Court ruled against parts of the 2006 Catalan autonomy statute in 2010. In Bosnia and Herzegovina, Bosniak parties seek to hold the common state together, while some of the Serbian parties pose a separatist challenge 
advocating independence for the Serb entity, Republika Srpska. ${ }^{16}$ Croat parties lobby for Croats to have a separate autonomous territorial entity, to get on par with the status of Serbs.

Figure 3 shows Spanish parties' position on the ethnonational dimension in 2011 and 2017. Among the mainstream parties, the People's Party (Partido Popular, PP) became a bit more majority nationalist in the last six years, whereas the Socialists (Partido Socialista Obrero Español, PSOE) maintained a stable and significantly more moderate position than PP. The two new parties, leftist Podemos (Spanish for: 'We can') and the Citizens' Party (Ciudadanos) have opted for different stances on the ethnonational dimension. Ciudadanos, which originated as a party defending the rights of Spanish speakers in Catalonia and then broadened its appeal to participate as a liberal party in state-wide competition, outflanks the PP on the majority nationalist end of the spectrum, while Podemos adopts a rather neutral stance. Among the Basque parties, the dominant and regionally governing Basque Nationalist Party (Euzko Alderdi Jeltzalea-Partido Nacionalista Vasco, EAJ-PNV) as well as the smaller and more radical alliance between separatist parties Euskal Herria Bildu (Basque for: 'Basque Country Unite', EH Bildu) kept their positions between 2011 and 2017. Catalan competition has been a lot less stable than Basque competition, reflecting the radicalizing process of secessionist outbidding among Catalan nationalist parties (Barrio and Rodríguez-Teruel 2017). The Republican Left of Catalonia (Esquerra Republicana de Catalunya, ERC) has long been advocating Catalan independence. Democratic Convergence of Catalonia (Convergència Democràtica de Catalunya, CDC) that was

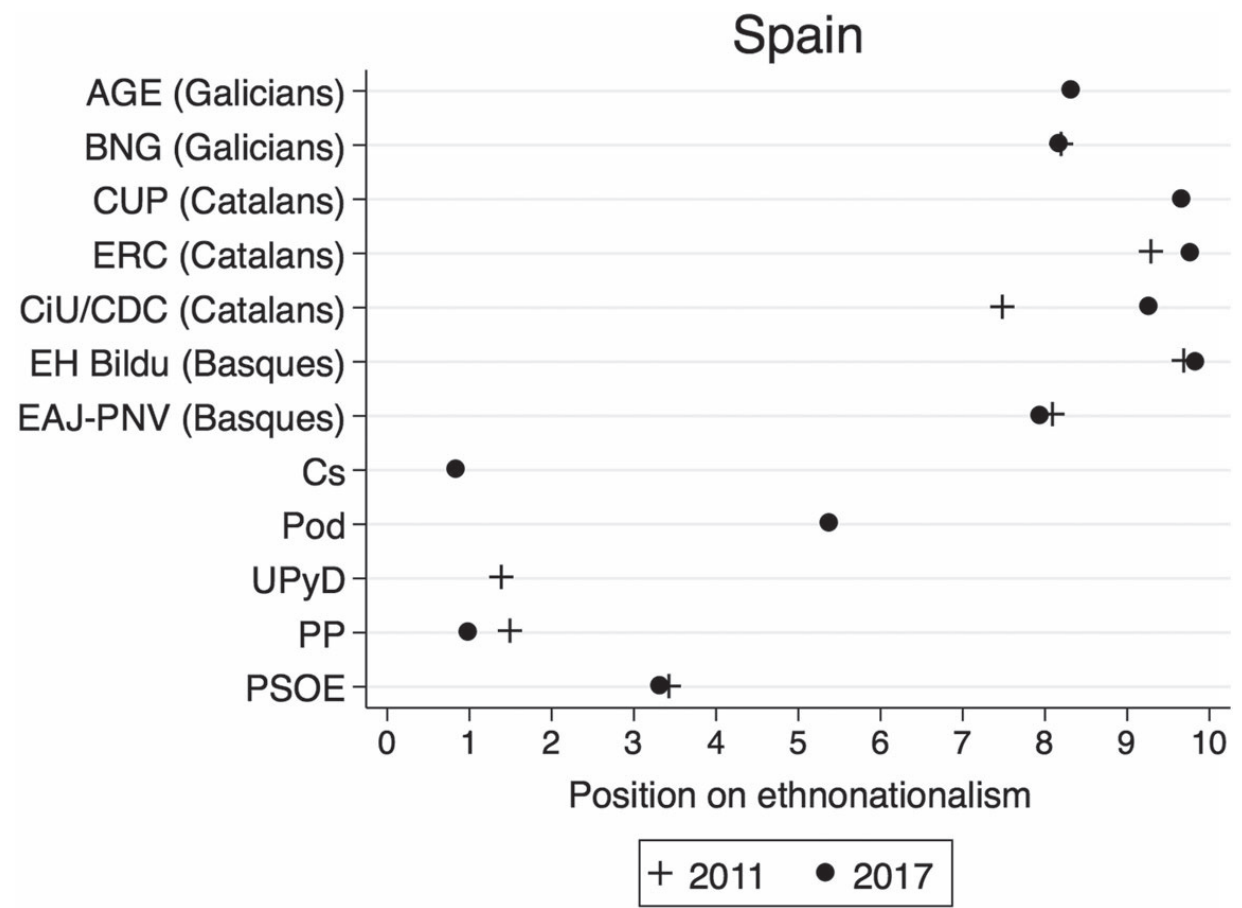

Figure 3. Party positions in Spain, 2011 and 2017. 
included as Convergence and Union (Convergencia i Unió, CiU, an alliance between CDC and the smaller party Unió) in 2011 used to be more moderate and autonomist and only turned secessionist for the regional elections in 2012 (CiU 2012, 8-16). This radicalization is reflected in a distinctively more radical position of CDC in our 2017 data. ${ }^{17}$ In addition, the new and leftist Popular Unity Candidacy (Candidatura d'Unitat Popular, CUP) entered the Catalan parliament in 2012 and adds to the secessionist minority nationalist spectrum in Catalonia. In line with case-based assessments in the literature, our data thus show growing centre-periphery polarization of Spanish party competition over time.

Figure 4 displays Bosnian parties' positions on the ethnonational dimension in 2011 and 2017. Bosnian party politics is segmented along the lines of ethnonational groups with competition happening predominantly within, but hardly across the Bosniak, the Serb and the Croat segments (Keil and Perry 2015, 84). This is reflected in the fact that most parties are either classified as Bosniak majority nationalist, or as Croat or Serbian minority nationalist parties by a majority of consulted experts. Only two parties that surpass our criteria for inclusion were not classified as appealing to a specific group: the Social Democratic Party (Socijaldemokratska Partija Bosne $i$ Hercegovine, SDP) and the small People's Party Work for Betterment (Narodna stranka radom za boljitak, NSRZB). In line with their non-nationalist appeal, these parties maintained similarly moderate positions on the ethnonational dimension, between 2011 and 2017.

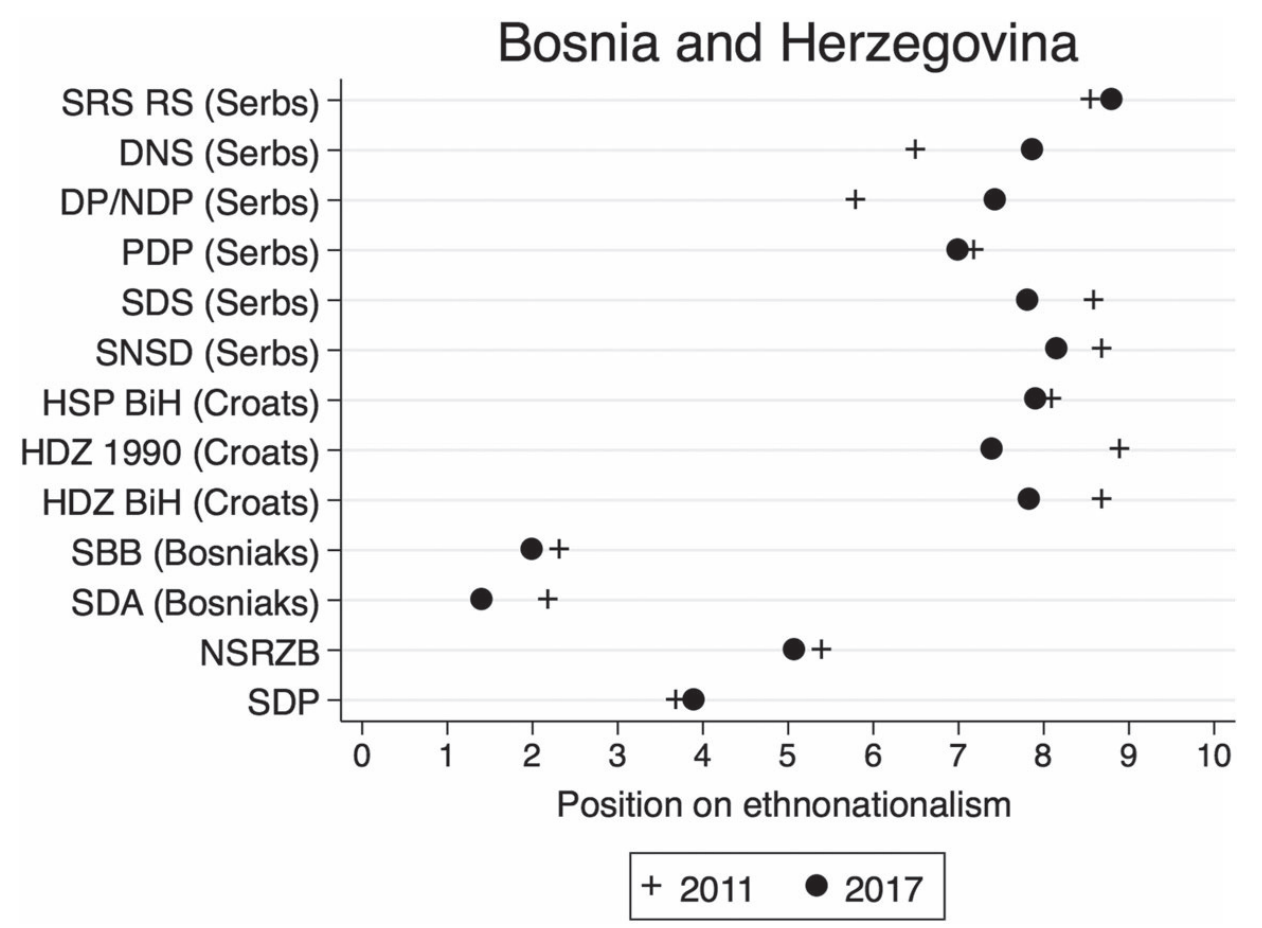

Figure 4. Party positions in Bosnia and Herzegovina, 2011 and 2017. 
In the camp of parties classified as Bosniak majority nationalist, the parties that were electorally most successful in the parliamentarian elections in 2014, the Party for Democratic Action (Stranka demokratske akcije, SDA, 27.87\% of votes in the Federation ${ }^{18}$ ), as well as the Union for a Better Future (Savez za bolju budućnost, SBB, $14.44 \%$ of votes in the Federation) became more nationalist between 2011 and 2017. This is in line with scholarly assessment of the 2014 general elections as 'one of the most divisive campaigns in years, further polarizing an environment characterized not only by the lack of reform, but by stagnation and even regression since 2006' (Keil and Perry 2015, 82). The 2014 elections fell between our surveys. Divisive nationalist campaigning in the Bosniak camp succeeded at the expense of the nonnationalist SDP, whose party leader was accused of showing too much readiness at accommodating Serbian demands for weakening central state institutions (Keil and Perry 2015, 85). Observed radicalization in the Bosniak camp also picks up the consequences of a shift in the SDA's leadership. Bakir Izetbegović became president of SDA in 2015 and controversially called for constitutional reform to create a Bosnian republic divided into five regions, abolishing the current entities (Radio Slobodna Evropa 26 May 2015).

In contrast to dynamics of outbidding within the Bosniak majority camp, our data show that all three Croat minority nationalist parties - the Croatian Democratic Union of BiH (Hrvatska demokratska zajednica BiH, $\mathrm{HDZ} \mathrm{BIH),} \mathrm{the}$ Croatian Democratic Union 1990 (Hrvatska demokratska zajednica 1990, HDZ 1990) and the Croatian Party of Rights of Bosnia and Herzegovina (Hrvatska stranka prava Bosne i Hercegovine, HSP BIH) - became more moderate over time. $^{19}$

Serbian minority nationalist parties show heterogeneous developments. The two most successful parties in Republika Srpska (Bosnia and Herzegovina's Serb entity), the Alliance of Independent Social Democrats (Savez nezavisnih socijaldemokrata, SNSD, 38.48\% of votes in the Republika Srpska) and the Serb Democratic Party (Srpska demokratska stranka, SDS, $32.67 \%$ of votes in Republika Srpska), as well as the Party of Democratic Progress (Partija demokratskog progresa, PDP) became more moderate, while two other smaller parties, the Democratic People's Alliance (Demokratski narodni savez, DNS, $5.72 \%$ ) and the Serb Radical Party (Srpska radikalna stranka RS, SRS RS, $5.72 \%)$ became more extreme. Another small party representing the Serb minority, the Democratic Party (Demokratska Partija, DP) merged with the National Democratic Party and renamed itself as National Democratic Movement (Narodni demokratski pokret, NDP) in 2013. At the same time, its leader, Dragan Čavić, remained the same. NDP had a more minority nationalist position in 2017 than DP in 2011. Moderation of SNSD was one of the scenarios Keil and Perry $(2015,85)$ considered possible in the aftermath of the 2014 election that saw Dodik's SNSD challenged by intra-ethnic competitors. 
All in all, we can thus observe tendencies of moderation among the Croat periphery, heterogeneous movements among Serbs, and tendencies of advocating a more decidedly nationalist stance among parties representing the Bosniaks.

\section{Conclusion}

In this research note, we evaluated the validity and reliability of the second round of the EPAC dataset on ethnonationalism in party competition in Europe, repeating a set of tests previously performed on the first round. The results showed that our 2017 data provides valid and reliable measures of party positions on an ethnonational and other dimensions of competition. With regard to internal validity, our descriptive analysis of experts' own policy preferences shows that a majority of experts has very moderate positions on ethnonationalism and can therefore be expected to judge parties objectively. In the case of Spain, where we could apply inferential methods to test more stringently for an effect of experts' own policy preferences on party placement, we found only a minor share of parties affected by bias. We consider Spain to be a most likely case for expert bias, due to the salient centre-periphery conflict and due to experts' own stances in this conflict, that are more pronounced than in all other cases. Cross-validating our data with the Regional Manifestos Project yielded a correlation of 0.57 , a very satisfying result in terms of convergent validity, given the different methodologies employed by the two projects.

In terms of reliability, global results of inter-expert correlation are very satisfying, in particular for party placement on the ethnonational dimension, the dimension of competition this project is primarily interested in. However, we have also shown that the standard deviation in expert judgments is heterogeneous across parties and dimensions. Experts can converge for one party, but diverge when judging another party in the same country, or converge when placing a party on one issue dimension, but diverge when placing the same party on another one. We therefore encourage researchers to include standard deviations by party and dimension into their analyses as a measure of uncertainty.

Making use of our fresh data, we illustrated how the dynamics of competition between majority and minority parties in Spain and Bosnia have been unfolding over the last six years. In line with case-based assessments, our data accurately shows how the independence conflict in Catalonia has been intensifying through more dominant independence claims voiced by minority nationalist parties in Catalonia, the shift of the People's Party to a more majority nationalist position and the entry of Ciudadanos into state-wide competition with an even more decidedly Spanish nationalist position. In the case of Bosnia, our results fall in line with a shift towards majority nationalism 
reflected in the fact that the new leadership of the major Bosniak party SDA advocated a state organization less fragmented along the lines of ethnic entities, turning Bosnia into a republic with five regions. This suggestion is vigorously opposed by major Serb parties and some of these parties also radicalized their positions between 2011 and 2017. Interestingly, the Croat and some of the smaller Serbian ethnonational parties moderated their stances over time, a finding that deserves further scrutiny.

Going beyond descriptives, combining the 2011 and 2017 edition into a longitudinal dataset allows testing the ethnic outbidding model of party competition (Horowitz 1985; Rabushka and Shepsle 1972) against alternative theories such as the model of nested competition (Zuber 2012) in the European context. This allows scholars to explore what factors lead to radicalization and secessionism, accounting for parties' strategic responses to each other over time. Furthermore, the data set also allows a systematic analysis of (ethno-) national parties' location in a multidimensional political space. A growing literature argues that (ethno-) regionalist parties actively compete on multiple political dimensions, rather than focusing exclusively on centre-periphery issues, such as territorial reform (Elias, Szöcsik, and Zuber 2015; Massetti 2009; Massetti and Schakel 2015). Finally, users of the data can study the structure of the political space in multinational European states. With the growing importance of the integration-demarcation conflict (e.g. Kriesi et al. 2008), European party systems are undergoing important changes. The financial crisis and the arrival of high numbers of asylum seekers have sharpened conflicts about national identity and belonging in Europe. In many places, parties that primarily emphasize non-economic, cultural issues and questions of national identity are challenging mainstream parties. Our longitudinal data that adds issues such as European integration and immigration to a finegrained assessment of parties' nationalism now allows for an analysis of how parties adjust their positions on identity issues over time, and how parties relate state-internal conflicts to their stances on a supranational integration project and the question of immigration.

\section{Notes}

1. We use 'mainstream party' as a residual category to refer to parties that do not seek to represent ethno-national groups in politics.

2. The dataset will be made available for download upon publication of this research note from www.christinazuber.com.

3. For an extended presentation of the motivation behind this data collection effort and for a detailed conceptualization of the ethnonational dimension of party competition, we refer the reader to Szöcsik and Zuber (2015).

4. In Belgium, some parties representing the Flemish majority demand secession. We adapted the wording accordingly. Please note that survey items on education in and of the minority and language and use of the minority languages 
are no longer included in 2017. Since we still ask for parties' stances on the overarching principle of cultural autonomy of which the two policies are specific instances, we made room for new survey items without losing a previous issue.

5. The Polity IV dataset characterizes Turkey and the Ukraine as 'anocracies' in 2014 (Marshall, Gurr, and Jaggers 2016). Our original selection criteria for democratic states were that these states have to be described as 'free' or 'partly free' by the Freedom House index and as a 'democracy' by the Polity IV dataset.

6. This definition draws on Chandra's (2005) definition of ethnic parties based on their appeal, rather than their support base. As explained in the introduction, the EPR-ETH project understands ethnicity in a wide sense, including cultural identity and shared history and language as possible markers, not just shared descent. Roma parties were excluded from the selection due to the absence of a territorial basis for group identity. We kept parties appealing to the Swedes in Finland in the selection since the Swedes are in fact territorially clustered in Southern and South Western Finland.

7. Information on whether directly elected regional assemblies exist was originally taken from Marks, Hooghe, and Schakel (2008). Several regional election results were again kindly provided by Arjan Schakel (Schakel 2011, see also: https:// www.arjanschakel.nl).

8. For a comparison, the response rate of the expert survey on party positions of Benoit and Laver $(2006,157)$ was $28 \%$.

9. We thank an anonymous referee for pointing us towards this possibility.

10. These are (1) a state-wide left-wing party, Podemos and (2) a Galician party, Alternativa Galega de Esquerda (Galician Alternative of the Left). Given that the former adopts a moderate stance on the ethnonational dimension (position 5.4) and the latter an extreme minority nationalist position (8.3) it does not seem to be the case that expert bias affects only extreme parties.

11. The interexpert correlation is computed as $\frac{\sigma_{\delta}^{2}+\sigma_{\varepsilon j}^{2}}{\sigma_{\delta}^{2}+\sigma_{\varepsilon j}^{2}+\sigma_{\varepsilon i}^{2}} \cdot \sigma_{\delta}^{2}$ refers to the variance between countries, $\sigma_{\varepsilon j}^{2}$ refers to the variance between parties and $\sigma_{\varepsilon i}^{2}$ refers to the variance between experts.

12. The Spearman - Brown formula is computed as $\frac{n r}{(1+(n-1) r)}$ where $n$ is the average number of experts and $r$ is the inter-expert correlation.

13. For the corresponding analysis of party positions on the economic and the cultural dimension of competition and parties' position toward immigration and European integration and immigration cf. Appendix D. Inter-expert correlation and reliability measures are weaker for these other dimensions. This is likely to result from the over-representation of (ethno- )national parties in our sample. These parties are primarily concerned with their primary, territorial dimension and might deliberately blur their positions, or simply have less pronounced positions, on the other dimensions (cf. Elias, Szöcsik, and Zuber 2015).

14. We further correlated the ethnonational dimension with the identitarian component of the centre-periphery dimension, since the definition of the identitarian component closely resembles the wording of our question asking experts for parties' stances on the ethnonational dimension:

As with the competential continuum, the identitarian one also has two extremes: on the one side, peripheral nationalism or the belief that the peripheral territory constitutes a nation and, as such, has the right to 
self-determination (i.e. secession); on the other side, state nationalism. (Alonso, Gómez, and Cabeza 2013, 191)

The correlation is 0.55 (significant at the 0.05 level).

15. Previous comparisons between expert survey data and data based on the content-analysis of manifestos yielded very similar results. Bakker et al. (2015, 149-150) correlate their data from the Chapel Hill Expert Survey with data from the Manifesto Project (Lehmann et al. 2017). For parties' left-right positions, the correlation is 0.575 ; for positions on European integration, the correlation is 0.59 .

16. Bosnia's territorial regime consists of four levels of government: (1) the central level, (2) the entity level (composed of Republika Srpska, mainly inhabited by people of Serb ethnicity, and the Federation of Bosnia and Herzegovina, mainly inhabited by Bosniaks and Croats) (3) the cantonal level (the Federation is itself composed of cantons) and (4) the local level. The Republika Srpska does not have a cantonal level of government.

17. CDC has in the mean time been re-founded as Partit Demòcrata Europeu Català (PDeCAT).

18. Representatives are elected separately in the two entities. 28 members of Bosnia's House of Representatives are elected in the Federation, 14 in the Serb Republic. The central electoral commission therefore provides the results by entity.

19. We could not find a case-based assessment of developments of the positions of Croat parties in the literature that would allow us to adjudicate whether our data has face validity with regard to moderation among the Croats.

\section{Acknowledgements}

We are indebted to Josefa Glass and Annika Stein for excellent research assistance, to all contributing experts for their readiness to share their knowledge with us, to Matthias Scantamburlo for advanced access to data from the Regional Manifestos Project, and to Luigi Curini for advice on how to test for expert bias. Three anonymous reviewers gave very helpful comments.

\section{Disclosure statement}

No potential conflict of interest was reported by the authors.

\section{Funding}

This work was supported by Deutsche Forschungsgemeinschaft [grant number Cluster of Excellence 16].

\section{References}

Adcock, R., and D. Collier. 2001. "Measurement Validity: A Shared Standard for Qualitative and Quantitative Research." American Political Science Review 95 (3): 529-546. 
Alonso, S. 2012. Challenging the State: Devolution and the Battle for Partisan Credibility: A Comparison of Belgium, Italy, Spain, and the United Kingdom. Oxford: Oxford University Press.

Alonso, S., B. Gómez, and L. Cabeza. 2013. "Measuring Centre-Periphery Preferences: The Regional Manifestos Project." Regional \& Federal Studies 23 (2): 189-211.

Bakker, R., C. de Vries, E. Edwards, L. Hooghe, S. Jolly, G. Marks, J. Polk, J. Rovny, M. Steenbergen, and M. A. Vachudova. 2015. "Measuring Party Positions in Europe: The Chapel Hill Expert Survey Trend File, 1999-2010." Party Politics 21 (1): 143-152.

Barrio, A., and J. Rodríguez-Teruel. 2017. "Reducing the Gap between Leaders and Voters? Elite Polarization, Outbidding Competition, and the Rise of Secessionism in Catalonia." Ethnic and Racial Studies 40 (10): 1776-1794.

Basile, L. 2015. "A Dwarf among Giants? Party Competition between Ethno-Regionalist and State-Wide Parties on the Territorial Dimension: The Case of Italy (1963-2013)." Party Politics 21 (6): 887-899.

Benoit, K., and M. Laver. 2006. Party Policy in Modern Democracies. New York: Routledge.

Brown, T. A. 2006. Confirmatory Factor Analysis for Applied Research. New York, London: The Guilford Press.

Cederman, L.-E., A. Wimmer, and B. Min. 2010. "Why do Ethnic Groups Rebel? New Data and Analysis." World Politics 62 (1): 87-119.

Chandra, K. 2005. "Ethnic Parties and Democratic Stability." Perspectives on Politics 3 (2): 235-252.

Chandra, K. 2006. "What is Ethnic Identity and Does it Matter?" Annual Review of Political Science 9: 397-424.

CiU. 2012. Programa electoral 2012: Catalunya 2020.

Curini, L. 2010. "Experts' Political Preferences and Their Impact on Ideological Bias. An Unfolding Analysis Based on a Benoit-Laver Expert Survey." Party Politics 16 (3): 299-321.

Elias, A., E. Szöcsik, and C. I. Zuber. 2015. "Position, Selective Emphasis and Framing: How Parties Deal with a Second Dimension in Competition." Party Politics 21 (6): 839-850.

Gómez, B., S. Alonso, and L. Cabeza. 2009. "Regional Manifestos Project [CSO200911241]." R\&D\&i National Plan, Ministry of Economy and Competitiveness, Government of Spain (Version 29.07.2016). Accessed February 12, 2018. www. regionalmanifestosproject.com.

Granberg, D., and T. A. Brown. 1992. "The Perception of Ideological Distance." The Western Political Quarterly 45 (3): 727-750.

Guibernau, M. 1997. "Nations Without States: Catalonia, a Case Study." In The Ethnicity Reader. Nationalism, Multiculturalism and Migration, edited by M. Guibernau, and J. Rex, 121-201. Cambridge: Polity Press.

Hepburn, E. 2009a. "Introduction: Reconceptualizing Sub-state Mobilization." Regional \& Federal Studies 19 (4-5): 477-99.

Hepburn, E. 2009b. "Regionalist Party Mobilisation on Immigration." West European Politics 32 (3): 514-35.

Hooghe, L., R. Bakker, A. Brigevich, C. de Vries, E. Edwards, G. Marks, J. Rovny, M. Steenbergen, and M. Vachudova. 2010. "Reliability and Validity of the 2002 and 2006 Chapel Hill Expert Surveys on Party Positioning." European Journal of Political Research 49 (5): 687-703.

Horowitz, D. L. 1985. Ethnic Groups in Conflict. Berkeley: University of California Press.

Keil, S., and V. Perry. 2015. "Back to Square One?: An Analysis of the 2014 General Elections in Bosnia and Herzegovina." Electoral Studies 38: 82-87. 
Kriesi, H., E. Grande, R. Lachat, M. Dolezal, S. Bornschier, and T. Frey. 2008. West European Politics in the Age of Globalization. Cambridge: Cambridge University Press.

Lehmann, P., T. Matthiess, N. Merz, S. Regel, and A. Werner. 2017. Manifesto Corpus. Version: 2017b. Berlin: WZB Berlin Social Science Center.

Marks, G., L. Hooghe, and A. H. Schakel. 2008. "Measuring Regional Authority." Regional and Federal Studies 18 (2-3): 111-121.

Marshall, M. G., T. R. Gurr, and K. Jaggers. 2016. "Polity IV Project. Political Regime Characteristics and Transitions, 1800-2016." Dataset Users' Manual. Accessed February 14, 2018. www.systemicpeace.org/inscr/p4manualv2016.pdf.

Massetti, E. 2009. "Explaining Regionalist Party Positioning in a Multi-Dimensional Ideological Space: A Framework for Analysis." Regional and Federal Studies 19 (45): 501-531.

Massetti, Emanuele, and Arjan H. Schakel. 2015. "From Class to Region: How Regionalist Parties Link (and Subsume) Left-right into Centre-periphery Politics." Party Politics 21 (6): 866-886.

Rabushka, A., and K. A. Shepsle. 1972. Politics in Plural Societies: A Theory of Democratic Instability. Columbus: Charles E. Merrill Publishing Company.

Radio Slobodna Evropa. 2015. "Bakir Izetbegović novi predsjednik SDA." Accessed February 14, 2018. https://www.slobodnaevropa.org/a/kongres-sda-bih-biranovog-lidera-stranke/27037112.html.

Scantamburlo, M., S. Alonso, and B. Gómez. 2018. "Democratic Regeneration in European Peripheral Regions: New Politics for the Territory?" West European Politics 41 (3): 615-639.

Schakel, A. H. 2011. "Regional Election Database." Accessed July 20, 2016. http://www. arjanschakel.nl.

Steenbergen, M. R., and G. Marks. 2007. "Evaluating Expert Judgments." European Journal of Political Research 46 (3): 347-366.

Szöcsik, E., and C. I. Zuber. 2015. "EPAC - A New Dataset on Ethnonationalism in Party Competition in 22 European Democracies." Party Politics 21 (1): 153-160.

Zuber, C. I. 2012. "Ethnic Party Competition Beyond the Segmented Market." Nationalities Papers 40 (6): 927-944. 